\title{
Road Network Designs in Wood Supply Analysis
}

by

\author{
H.D. Walker ${ }^{1}$ and W.H. Lougheed ${ }^{2}$
}

\section{Abstract}

A system for designing timber management strategies which considers the location, construction timing, and standards of road networks is presented. The system allows the effects of alternative road networks on economic wood supplies and timber management strategies to be assessed. A geographic information system is used to update stand attributes in response to alternative road networks, prior to analysis using a linear-programming-based forest planning model. A case study illustrating the planning system is briefly reviewed and instructions for obtaining system software are provided.

Key Words: timber management planning, geographic information system, spatial analysis, road network design, linear programming, wood supply analysis.

\section{Résumé}

Un système de conception des stratégies de gestion de la ressource ligneuse qui tiendrait compte de la localisation, de l'échéancier de construction, et des critères des réseaux routiers est présenté dans cet article. Le système permet d'étudier les effets de différentes possibilités de réseau routier sur l'approvisionnement économique et sur les statégies de gestion de la matière ligneuse. Un système d'informaiton géographique est utilisé pour mettre à jour les données relatives aux peuplements, en réponse aux différents réseaux routiers, avant d'analyser le problème en utilisant un modèle de programmation linéaire adapté à la foresterie. Une étude de cas illustrant le système de planification est brièvement étudié et les instructions pour obtenir le logiciel du système sont fournies.

Mots-clés: planification de la gestion de la matière ligneuse, système d'information géographique, analyse spatiale, conception de réseaux routiers, programmation linéaire, analyse de l'approvisionnement en bois.

\section{Introduction}

The design of timber management strategies requires controlling both the location and the timing of management actions. As well as scheduling harvesting and silvicultural activities within stands, this includes designing alternative road networks for transporting wood to storage locations and mills. The location, construction timing, and standards of road networks affect the areas accessible for forest operations and the expected haul costs for each cut block.

Designing and evaluating several alternative road networks is generally impracticable, because of the complexity and time-consuming nature of the task. Planners are thus typically restricted to reviewing only one or two alternative networks, often superficially at that. However, recent advances in spatial analysis realized with the use of a geographic information system (GIS) such as the Environmental Systems Research Institute (ESRI) ARC/INFO system (ESRI 1987) offer a means of improving road network design, by partially automating the process of assigning spatial and temporal stand attributes to reflect alternative networks. A GIS allows one to maintain a relational database linking the geographic location of features, such as forest stands, with their attributes.

This paper describes a system for designing timber management strategies which uses a GIS to help evaluate alternative road networks in terms of their effects on economic wood supplies. A simple wood supply model having

'Weldwood of Canada Limited, Hinton Division, 760 Switzer Drive. Hinton, Alberta T7V 1V7 ${ }^{2}$ Northwood Pulp and Timber Limited, Woods Division, Box 9000, Prince George, B.C. V2L 4 W2 a linear programming (LP) structure is first presented, followed by a description of the manner in which a GIS may be used to readily update stand attributes in response to alternative road networks. A case study illustrating the planning system is briefly reviewed. A detailed discussion of the case study, and copies of all non-licensed programs required to implement the system, may be found in Lougheed (1988) and Lougheed and Walker (1988).

\section{Wood Supply Model Structure}

The Timber Resource Allocation Method (Timber RAM) modelling system (Navon 1971) was one of the first largescale attempts at modelling the timber management planning problem using LP. A shortcoming of Timber RAM, and its successors MUSYC (Johnson and Jones 1980) and FORPLAN (Johnson et al. 1986), has been the difficulty of incorporating spatial considerations (Chappelle et al. 1976; Iverson and Alston 1986) into the LP structure. In the case of Timber RAM and MUSYC, spatial analyses were limited to increasing the percentage of accessible stand class area over time, mimicking road construction projects. FORPLAN allows further spatial analyses, although at a cost of increased model size and a requirement for integer programming formulations. (See Dykstra [1984] for an introduction to mathematical programming applications in forestry.)

The following simple model may be represented using any of the above modelling systems. We chose Timber RAM because of its availability, relative simplicity, and ease of use. The mathematical structure has an 80-year planning horizon, a 25-year critical period for optimizing objective functions, and 16 five-year planning periods. Data and exogenous 


\section{Table 1. Data elements}

\begin{tabular}{|c|c|c|}
\hline Name & Notation & Function \\
\hline Stand class area & $a_{i}$ & $\begin{array}{l}\text { Initial area of stand class i } \\
\text { (ha) }\end{array}$ \\
\hline Area accessibility & $\mathrm{ac}_{\mathrm{ik}}$ & $\begin{array}{l}\text { Percentage of stand class } i \\
\text { accessible in period } k \text {, where } \\
k=1,2, \ldots t_{i}\end{array}$ \\
\hline $\begin{array}{l}\text { Timing of access for } \\
\text { treatment }\end{array}$ & $b_{i j k}$ & $\begin{array}{l}1.0 \text { if stand class i assigned } \\
\text { to regime } \mathrm{j} \text { produces volume } \\
\text { in period } \mathrm{k} ; 0.0 \text { otherwise }\end{array}$ \\
\hline Treatment cost & $\mathrm{C}_{i j \mathrm{k}}$ & $\begin{array}{l}\text { Cost }(\$) \text { incurred in period } k \\
\text { from each hectare of stand } \\
\text { class i assigned to regime } j\end{array}$ \\
\hline $\begin{array}{l}\text { Periodic flow } \\
\text { tolerance }\end{array}$ & $f_{k}$ & $\begin{array}{l}\text { Maximum percentage change } \\
\text { in harvest level from period } \\
\mathrm{k}-1 \text { to period } \mathrm{k} \text {, where } \mathrm{k}=1 \text {, } \\
2, \ldots 16\end{array}$ \\
\hline $\begin{array}{l}\text { Periodic harvest } \\
\text { level }\end{array}$ & $h_{k 1}$ & $\begin{array}{l}\text { Minimum harvest volume of } \\
\text { species } I \text { in period } k \text {, where } \\
1=1,2,3\end{array}$ \\
\hline $\begin{array}{l}\text { Number of stand } \\
\text { classes }\end{array}$ & $\mathrm{m}$ & $\begin{array}{l}\text { Initial number of stand } \\
\text { classes }\end{array}$ \\
\hline Number of regimes & $n$ & $\begin{array}{l}\text { Initial number of silvicultural } \\
\text { regimes }\end{array}$ \\
\hline $\begin{array}{l}\text { Last period of } \\
\text { constrained species } \\
\text { harvest volume }\end{array}$ & $p_{1}$ & $\begin{array}{l}\text { Last period in which } \\
\text { minimum harvest levels for } \\
\text { species } 1 \text { are in effect, where } \\
I=1,2,3\end{array}$ \\
\hline Discount rate & $r$ & Real (deflated) discount rate \\
\hline $\begin{array}{l}\text { Species harvest } \\
\text { volume }\end{array}$ & $\mathrm{s}_{\mathrm{ijk \textrm {k }}}$ & $\begin{array}{l}\text { Volume }\left(\mathrm{m}^{3}\right) \text { of species } \mathrm{I} \text { har- } \\
\text { vested in period } \mathrm{k} \text { from each } \\
\text { hectare of stand class } \mathrm{i} \\
\text { assigned to regime } \mathrm{j} \text {, where } \\
\mathrm{I}=1,2,3\end{array}$ \\
\hline $\begin{array}{l}\text { Last period of } \\
\text { restricted access }\end{array}$ & $t_{i}$ & $\begin{array}{l}\text { Last period in which only a } \\
\text { percentage of stand class i } \\
\text { may be accessed }\end{array}$ \\
\hline Total volume & $v_{i j k}$ & $\begin{array}{l}\text { Total volume }\left(\mathrm{m}^{3}\right) \text { harvested } \\
\text { in period } \mathrm{k} \text { from each hec- } \\
\text { tare of stand class i assigned } \\
\text { to regime } \mathrm{j}\end{array}$ \\
\hline Minimum volume & $z$ & $\begin{array}{l}\text { Minimum total volume }\left(\mathrm{m}^{3}\right) \\
\text { obtained over } 25 \text { years }\end{array}$ \\
\hline
\end{tabular}

variable notation is shown in Table 1. Two LP formulations, volume maximization and cost minimization with constrained volume production, are used.

The volume maximization formulation is used to estimate the maximum productive capacity of the forest, under each of the alternative roading options, to produce total harvest volume over 25 years. Costs of attaining this volume are unconstrained, so a measure of the effectiveness of the set of management regimes for producing volume is obtained.

The cost minimization formulation is used to identify the lowest-cost strategy for achieving a particular total harvest volume over 25 years. The cost minimization formulation is employed, under each of the alternative access options, after the volume maximization formulation. The maximum volume level from the first formulation is established as the required volume level, and the minimum-cost strategy for attaining this level is determined. A measure of the efficiency of the set of management regimes for producing volume may be obtained by successive LP runs constrained to progressively lower volume levels. The result of this series of LP runs is a set of volume-cost tradeoff points and associated timber management strategies.

\section{Variables}

Several possible treatment regimes (sequences of silvicultural treatments) are defined for each stand class, where a stand class is a collection of individual stands considered to have similar biological and economic attributes. Each alternative combination of treatment regime and stand class defines a decision variable. The level of a decision variable is the area, in hectares, of a particular stand class assigned to that treatment regime.

Composite variables are used to reflect harvest volume flow constraints and accessibility restrictions (defined below). Decision and composite variable notation is shown in Table 2.

\begin{tabular}{|c|c|c|}
\hline Name & Notation & Definition \\
\hline $\begin{array}{l}\text { Management } \\
\text { variables }\end{array}$ & $X_{i j}$ & $\begin{array}{l}\text { Area (hectares) of stand class } i \\
\text { assigned to regime } j\end{array}$ \\
\hline $\begin{array}{l}\text { Accessibility } \\
\text { variables }\end{array}$ & $A C_{i k}$ & $\begin{array}{l}\text { Area of stand class } i \text { accessed in } \\
\text { period } k, k=1,2, \ldots t_{i} \text {, and } t_{i} \text { is } \\
\text { the last period in which only a } \\
\text { percentage of stand class } i \text { may } \\
\text { be accessed }\end{array}$ \\
\hline $\begin{array}{l}\text { Periodic harvest } \\
\text { level variables }\end{array}$ & $H P_{k}$ & $\begin{array}{l}\text { Total harvest level }\left(\mathrm{m}^{3}\right) \text { from all } \\
\text { stand classes in period } k \text {, where } \\
k=0,1,2, \ldots 5\end{array}$ \\
\hline
\end{tabular}

\section{Objective Functions}

A separate objective function is used for each formulation. Objective functions used are maximization of volumes harvested (from clearcut harvest and commercial thinnings) and minimization of discounted treatment costs (establishment, tending, harvest, and transportation costs). The volume maximization objective function has the form

$$
\begin{aligned}
& \text { Maximize VOLUME }\left(\mathrm{m}^{3} / 5 \text { periods }\right)= \\
& \qquad \sum_{i=1}^{m} \sum_{j=1}^{n} \sum_{k=1}^{5} \mathrm{v}_{\mathrm{ijk}} \cdot \mathrm{X}_{\mathrm{ij}} .
\end{aligned}
$$

The cost minimization objective function has the form

Minimize COST $(\$ / 5$ periods $)=$

$$
\sum_{i=1}^{m} \sum_{j=1}^{n} \sum_{k=1}^{5} c_{i j k} \cdot x_{i j} /(1+r)^{5 k-2.5} .
$$

All treatment costs are assumed to be incurred at the midpoint of each planning period.

\section{Constraint Functions}

Area availability constraint functions (one for each initial stand class) ensure that the total area of each initial stand class assigned to the various regimes does not exceed the total available area of that stand class. These have the form

$$
\sum_{j=1}^{n} x_{i j} \leq a_{i} \text {, for } i=1,2, \ldots m \text {. }
$$

Area accessibility constraint functions (up to five for each initial stand class) restrict by period the area accessible for management. These reflect the different amounts and timings of area available for management from alternative road networks. These have the form 
$A C_{i k} \leq a c_{i k} \cdot a_{i}$, for $i=1,2, \ldots m ; k=1,2, \ldots t_{i}$,

where the composite variable $\mathrm{AC}_{\mathrm{ik}}$ is defined as

$A C_{i k}=\sum_{j=1}^{n} b_{i j k} \cdot x_{i j}$, for $i=1,2, \ldots m ; k=1,2, \ldots t_{i}$

A minimum volume level constraint function ensures that the total volume level produced from harvests occurring during the critical period is at least equal to a specified minimum volume level. This function links the two objective functions by specifying the volume level for which the cost objective is optimized. It has the form

$$
\sum_{i=1}^{m} \sum_{j=1}^{n} \sum_{k=1}^{5} \mathrm{v}_{i j k} \cdot \mathrm{x}_{i j} \geq \mathrm{z}
$$

Moderation of harvest level fluctuations during the planning horizon is achieved by flow constraint functions which restrict harvest levels in each period to a percentage range above and below the harvest level in the preceding period. Increases to harvest levels are restricted by

$H P_{k} \leq\left(1+f_{k}\right) H P_{k-1}$, for $k=1,3, \ldots 16$,

where the composite variable $\mathrm{HP}_{\mathrm{k}}$ is defined as

$H P_{k}=\sum_{i=1}^{m} \sum_{j=1}^{n} v_{i j k} \cdot x_{i j}$, for $k=1,2, \ldots 16$.

Decreases to harvest levels are restricted by

$H P_{k} \geq\left(1-f_{k}\right) H P_{k-1}$, for $k=1,3, \ldots 16$

Current harvest levels are period zero (0) levels.

Minimum total species volume requirements for specified periods are restricted by periodic harvest constraint functions, having the form

$$
\begin{gathered}
\sum_{i=1}^{m} \sum_{j=1}^{n} \mathrm{~s}_{\mathrm{ijkl}} \cdot \mathrm{X}_{\mathrm{ij}} \geq \mathrm{h}_{\mathrm{k} 1} \text {, for } \mathrm{k}=1,2 \ldots \mathrm{p}_{\mathrm{l}} \text {, and } \\
\mathrm{I}=1,2,3 .
\end{gathered}
$$

\section{Linear Programming Formulations}

The volume maximization formulation is

\section{Maximize}

$\operatorname{VOLUME}\left(\mathrm{m}^{3} / 5\right.$ periods $)=\sum_{i=1}^{m} \sum_{j=1}^{n} \sum_{k=1}^{16} \mathrm{v}_{i \mathrm{jk}} \cdot \mathrm{x}_{\mathrm{ij}}$,

subject to

$$
\sum_{j=1}^{n} x_{i j} \leq a_{i}, \text { for } i=1,2, \ldots m \text {, }
$$

$A C i_{k} \leq a c_{i k} \cdot a_{i}$, for $i=1,2, \ldots m ; k=1,2, \ldots t_{i}$

$\sum_{j=1}^{n}\left(b_{i j k} \cdot X_{i j}\right)-A C_{i k}=\underset{l}{0.0, \text { for } i=1,2, \ldots m ~ a n d ~}$

$H P_{k}-\left(1+f_{k}\right) H P_{k-1} \leq 0.0$, for $k=1,2, \ldots 16$,

$\mathrm{HP}_{\mathrm{k}}-\sum_{i=1}^{m} \sum_{j=1}^{n} \mathrm{v}_{\mathrm{ijk}} \cdot \mathrm{x}_{\mathrm{ij}}=0.0$, for $\mathrm{k}=1,2, \ldots 16$,

$H P_{k}-\left(1-f_{k}\right) H P_{k-1} \geq 0.0$, for $k=1,2, \ldots 16$,

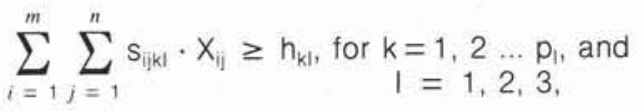

$x_{i j} \geq 0.0$, for $i=1,2, \ldots m ; j=1,2, \ldots n$.

Equation [11] describes a set of non-negativity constraint functions, which ensure that all decision variables are assigned non-negative values.

\section{The cost minimization formulation is}

Minimize

$\operatorname{COST}(\$ / 5$ periods $)=$

$$
\sum_{i=1}^{m} \sum_{j=1}^{n} \sum_{k=1}^{5} c_{i j k} \cdot x_{i j} /(1+r)^{5 k-2.5}
$$

subject to

$\sum_{j=1}^{n} x_{i j} \cdot \leq a_{i}$, for $i=1,2, \ldots m$,

$A C_{i k} \leq a c_{i k} \cdot a_{i}$, for $i=1,2, \ldots m ; k=1,2, \ldots t_{i}$,

$\sum_{j=1}^{n}\left(b_{i j k} \cdot X_{i j}\right)-A C_{i k}=0.0$, for $i=1,2, \ldots m$
and $k=1,2, \ldots t_{i}$,

$\sum_{i=1}^{m} \sum_{j=1}^{n} \sum_{k=1}^{5} v_{i j k} \cdot x_{i j} \geq z_{i}$

$H P_{k}-\left(1+f_{k}\right) H P_{k-1} \leq 0.0$, for $k=1,2, \ldots 16$,

$H P_{k}-\sum_{i=1}^{m} \sum_{j=1}^{n} v_{i j k} \cdot x_{i j}=0.0$, for $k=1,2, \ldots 16$,

$H P_{k}-\left(1-f_{k}\right) H P_{k-1} \geq 0.0$, for $k=1,2, \ldots 16$,

$\sum_{i=1}^{m} \sum_{j=1}^{n} \mathrm{~s}_{i j k \mathrm{l}} \cdot \mathrm{x}_{\mathrm{ij}} \geq \mathrm{h}_{\mathrm{k} \mid}, \begin{array}{r}\text { for } \mathrm{k}=1,2 \ldots \mathrm{p}_{\mathrm{l}}, \\ \text { and } \mathrm{i}=2,3,\end{array}$

$X_{i j} \geq 0.0$, for $i=1,2, \ldots m ; j=1,2, \ldots n$.

\section{The Planning System}

Within the planning system, haul costs are calculated for each of the first five periods. Minimum cost and access time are assigned as attributes to individual stands, to account for road construction. Stand access time is assumed to be the period in which the haul cost first reaches a minimum. Based on the relationship of expected travel time from each stand to the mill, "haul zones" are generated. Aggregation for each time period, based on both traditional inventory criteria and the generated criteria of access timing and haul cost, permits determining forest age structures by haul zone for each future time period. Alternative roading strategies result in different forest age structures over time.

The system consists of two primary activities, data acquisition and simulation (Figure 1).

\section{Data Acquisition}

Two levels of GIS-resident data are required. Strata data are required to categorize each stand and forest data are required to characterize the forest as a whole. Data acquisition culminates with stratification of the forest area into stand classes, based upon temporal and spatial data elements. 


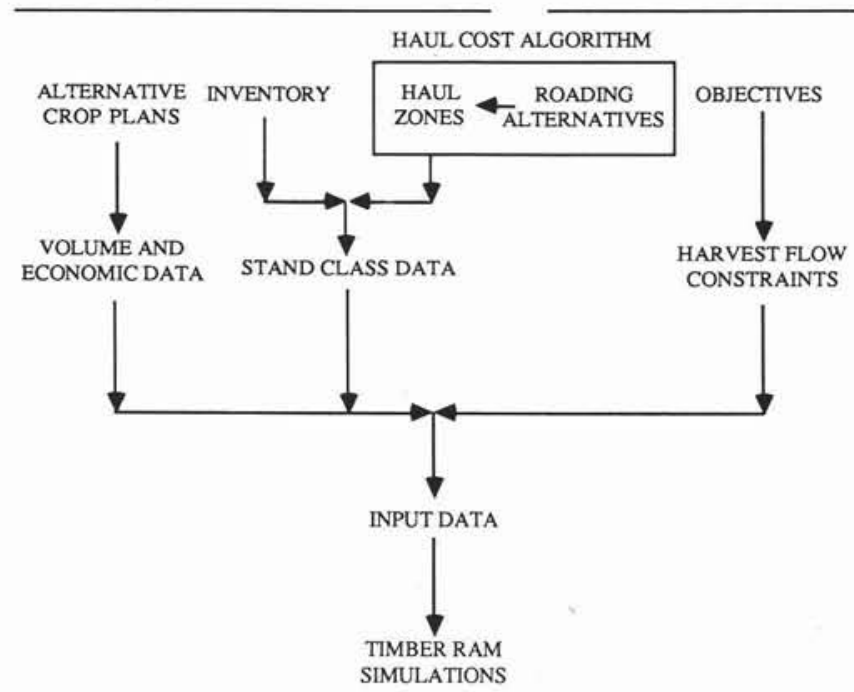

Figure 1. Management planning system.

Forest-level objectives and constraints are derived from the physical and economic requirements of the organization managing the forest property. Temporal data include the total volume and cost objectives and constraints on total volume harvest flows. Spatial data include digital maps containing roading alternatives for five periods into the future. Procedures suggested for designing roading alternatives vary from subjective placement to optimal road location (Weintraub and Navon 1976; Jones et al. 1986, Kirby et al. 1986). Roading alternatives are the bases for determining transportation costs.

Temporal strata-level data include age-dependent harvest costs and harvest volumes. Volume development curves, reflecting the growth and yield of a stand over time in response to alternative silvicultural regimes, and roadside harvest costs (age-dependent costs of transforming standing timber to piles at roadside), are derived.

Spatial strata-level data include location, size, accessibility, timing of access for management, and the last period of restricted access. These are derived using the haul cost algorithm described below.

The haul cost algorithm bridges the gap between stratalevel and forest-level data, as shown by the boxed area in Figure 1. Zones of equivalent haul cost (haul zones) are derived as one of the criteria for stratifying the forest into stand classes. Forest-level roading alternatives affect the area in each stand class over time.

The haul cost algorithm is implemented using two CPL (Command Processing Language; Landy 1986) routines. The first routine, DEFBAT.CPL, is a pre-processor which creates a CONTROL file for executing the second CPL routine. Executed as an interactive program, DEFBAT.CPL prompts the user for the data listed in Table 3. A detailed description of the map coverages (digital maps and associated attribute files) used in this process is given in Table 4. Once verified, coverage names are written from the coverage files to the CONTROL file.

The second routine, HAULCOST.CPL, performs the haul cost analysis according to the specifications in the CONTROL file. HAULCOST.CPL attaches the haul cost and time of access attributes, for each stand in the forest, to an INVEN-
TORY file. The procedure used within HAULCOST.CPL is as below.

\begin{tabular}{|c|c|c|}
\hline Data & Format & Comments \\
\hline ROAD & $\begin{array}{l}\text { map } \\
\text { coverage }\end{array}$ & $\begin{array}{l}\text { One map of all roads for } 5 \text { five-year } \\
\text { planning periods }\end{array}$ \\
\hline STAND & $\begin{array}{l}\text { map } \\
\text { coverage }\end{array}$ & Up to 20 forest stand maps \\
\hline $\begin{array}{l}\text { INVENTORY } \\
\text { FILE }\end{array}$ & $\begin{array}{l}\text { attribute } \\
\text { file }\end{array}$ & $\begin{array}{l}\text { Name of up to } 20 \text { files containing } \\
\text { STAND attributes }\end{array}$ \\
\hline $\begin{array}{l}\text { RELATE } \\
\text { ITEM }\end{array}$ & name & $\begin{array}{l}\text { One item name common for each } \\
\text { STAND and INVENTORY file }\end{array}$ \\
\hline BARRIER & $\begin{array}{l}\text { map } \\
\text { coverage }\end{array}$ & $\begin{array}{l}\text { Up to } 20 \text { polygon coverages of } \\
\text { physical barriers to access }\end{array}$ \\
\hline $\begin{array}{l}\text { SEARCH } \\
\text { TOLERANCE }\end{array}$ & number & $\begin{array}{l}\text { maximum distance from a stand to } \\
\text { the nearest road for access to be } \\
\text { achieved }\end{array}$ \\
\hline $\begin{array}{l}\text { HAUL } \\
\text { SPEED }\end{array}$ & number & $\begin{array}{l}\text { Up to five classes of road assigned } \\
\text { a haul speed }(\mathrm{km} / \mathrm{h})\end{array}$ \\
\hline $\begin{array}{l}\text { ACCESS } \\
\text { POINTS }\end{array}$ & number & $\begin{array}{l}\text { Two-way travel time between up to } \\
\text { five access points and haul } \\
\text { destination(s) }\end{array}$ \\
\hline
\end{tabular}

\begin{tabular}{|c|c|}
\hline Coverage & Description \\
\hline ROADS & $\begin{array}{l}\text { Line coverage. Two-digit code to indicate the } \\
\text { period first available and road class. For } \\
\text { example, " } 25 \text { "' identifies a class } 5 \text { road avail- } \\
\text { able in period 2. }\end{array}$ \\
\hline STAND & $\begin{array}{l}\text { Polygon coverages. An INVENTORY file must } \\
\text { contain the stand attribute data, linked by the } \\
\text { RELATE ITEM. }\end{array}$ \\
\hline BARRIER & $\begin{array}{l}\text { Polygon coverages. Normally a subset of STAND } \\
\text { coverages, i.e. Iakes and two-line (major) rivers. } \\
\text { Two-line rivers must break at a bridge or a } \\
\text { planned bridge. Islands, or "donuts" within } \\
\text { barrier polygons result in errors, and must be } \\
\text { removed from the barrier coverages. }\end{array}$ \\
\hline
\end{tabular}

1. Initialize. Read coverage and numeric data from the CONTROL file.

2. Create ROADS coverage. Create ROADS coverage representing the road networks as they would exist during five periods in the future. ROADS is coded to enable extracting of the roads existing during each period (ROAD1 through ROAD5), using the ARC ARCEDIT utility (ESRI 1987).

3. Generate minimum-distance line coverages. Line coverages MINARC1 through MINARC5 are created containing all ROAD arcs existing in that period, the associated MINDST arcs, and all intersected BARRIER polygons. This is completed using the Fortran-77 program MINARC.F77. The program reads the arcs, removes barriers, and prints all MINDST arc endpoint coordinates to scratch files (MINDST1 for ROAD1, MINDST2 for ROAD2, etc.). The ARC GENERATE (ESRI 1987) utility creates the ARC/INFO coverages MINARC1 through MINARC5 from the scratch files.

If the distance between a stand and the nearest road is greater than the search tolerance, the stand is considered inaccessible at that time. With a fine road network, a small search tolerance is applicable, whereas broad road corridors require a large search tolerance to approximate construction of access roads. Sections of the MINDST arcs which 
intersect BARRIER polygons are deleted, with hauling assumed to be along the perimeter of the BARRIER ploygon. To link the MINARC and STAND coverages, each of the minimum distance arcs in the MINARC coverages is assigned the same id as the associated stand polygon.

4. Calculate arc travel times. Arc travel times are assigned to each arc in the five MINARC line coverages. The travel times are dependent on the arc length and the haul speed, with the haul speed determined by the road class. INFO (Henco Software 1985) processing is used for calculating arc travel times and assigning these times as the impedance or "cost" of travelling the arc.

5. Calculate cummulative travel times. Calculate the minimum cumulative time required to travel from a forest access point to each arc in the network. The ARC ALLOCATE utility (ESRI 1987) is used to perform this procedure. ALLOCATE determines the minimum-impedance path from the access points to each arc in the network, storing the cumulative impedance (time) as an attribute of each arc. INFO processing is used to add the two-way travel time between the mill and the forest access point for each stand.

6. Calculate haul costs. Calculate the haul cost $\left(\$ / \mathrm{m}^{3}\right)$ from the cumulative haul time of each arc in the five MINARC coverages. This procedure is performed only for those MINDST arcs associated with a stand in one of the STAND coverages. Haul cost is a function of the time required for a round-trip haul and the hourly labour (regular time and overtime) and machine rates (tractor and trailer). The INFO program COST accesses the cumulative impedance attributes in the MINARC coverage, calculates the haul costs, and writes the stand identifier and haul cost to a temporary file. Five temporary files are created, MINARC1.TAB through MINARC5.TAB

7. Determine timing of access for each stand. Determine the period at which the haul cost first reaches a minimum. This period is considered as the time of first access The period and the associated haul cost are written as attributes to the appropriate INVENTORY file. This procedure is implemented in INFO, using both interactive and program formats. The interactive sections relate the MINARCX.TAB files with the STAND coverage, which, in turn, is related to the INVENTORY file. The INFO program TRANSFER calculates, from the MINARCX.TAB files, the period of first access, and the associated haul cost for each stand in the STAND coverages. The resulting minimum cost period (MCP) and minimum cost (MC) for each arc are written as attributes to the INVENTORY file.

8. Determine stand class areas. Stand class areas are calculated using the inventory map coverages maintained on the GIS. INFO reports are used to perform the stratification based on haul zone, stratum, and age class. The stratified areas are subsequently used in simulation.

\section{Simulation}

Simulation consists of implementing the mathematical structure within the LP framework. The LP package XMP (Marsten 1986) accepts the input matrix generated by Timber RAM from the forest-level and strata-level data, and solves the LP problem. Minor changes to Timber RAM were made to include up to three volume development curves for each stand class, thereby allowing species-specific volume constraints. Timber RAM was also modified to provide reports of harvest volume by species, and harvest area totals by haul zone. These modifications were specific to the requirements of the Case Study.

\section{Case Study}

A $980-\mathrm{km}^{2}$ project area was located near Thunder Bay, Ontario. The area consisted of approximately 66500 ha of productive forest land within the Dog River - Mattawin Forest, a $6773-\mathrm{km}^{2}$ area of Crown Land managed by Great Lakes Forest Products Ltd. (GLFP) under a Forest Management Agreement (Ontario Ministry of Natural Resources 1985). Major species represented were: spruce (Picea glauca [Moench] Voss and Picea mariana [Mill.] B.S.P.), fir (Abies balsamea [L.] Mill.), jack pine (Pinus banksiana Ait.), aspen (Populus tremuloides Mitchx.), and birch (Betula papyrifera Marsh.). GLFP staff provided project data.

A preliminary stratification was used to assess requirements for age-dependent volume and economic data. Ten strata were recognized and alternative treatment regimes were developed for each stratum. For each regime, volume development curves were derived for each stratum using the stratum species composition (weighted average, by area) and the stratum density (weighted average, by area) applied to the pure species curves of Plonski (1981).

Area-based costs (\$/ha for scarification, planting, seeding, and herbiciding) were provided by GLFP staff. Volumebased costs were comprised of harvest costs and haul costs. Age-dependent harvest costs for natural stands and plantations were calculated using procedures described in Lougheed (1988). Haul costs were calculated using HAULCOST.CPL.

\section{Alternative Road Networks}

Restricted access due to road network construction was permitted for five five-year periods. Two roading alternatives were defined for the project area. Network 1 ( $258 \mathrm{~km}$ of roads) was acquired from GLFP records (Great Lakes Forest Products, n.d.), along with estimates of the proposed areas to be harvested, with no road construction planned for Period 5. Network 2 ( $238 \mathrm{~km}$ of roads) was contrived, save for the two Class 2 roads existing in Period 1 . The objective of defining Network 2 was to assess the effects of an alternative access option on sustainable harvest levels, costs and treatment schedules. MINARC maps for portions of the two networks are shown in Figures 2 and 3 . Table 5 shows the area accessed by each network over time.

\begin{tabular}{cccccc}
\hline \multirow{2}{*}{ Table 5. Area accessed by Networks $\mathbf{1}$ and $\mathbf{2}$ over time } \\
\hline \multirow{2}{*}{ Period } & \multicolumn{2}{c}{ Network $\mathbf{1}$} & & \multicolumn{2}{c}{ Network 2 } \\
\cline { 2 - 3 } \cline { 5 - 6 } \cline { 5 - 6 } & Area (ha) & \% of Total & & Area (ha) & \% of Total \\
\hline 1 & 7483 & 17 & & 8397 & 17 \\
2 & 8546 & 19 & & 21502 & 42 \\
3 & 34442 & 77 & & 34557 & 68 \\
4 & 44641 & 100 & & 38715 & 76 \\
5 & 44641 & 100 & & 50694 & 100 \\
\hline
\end{tabular}

To assess the effects of roading, haul costs, and timing of access on sustainable harvest levels, mill gate costs and harvest schedules, several problem formulations based upon Networks 1 and 2 were analyzed. Table 6 describes the alternative problem formulations. Each alternative required the accessed area to be stratified into stand classes.

The simplest area stratifications were for the CONTROL and NET1C alternatives. Both assumed a constant haul cost, resulting in stratification of the respective forest bases by age classes within strata. Figure 4 shows the area by stratum for the CONTROL alternative. Age classes were omitted for clarity, and for comparison with other forest bases. 


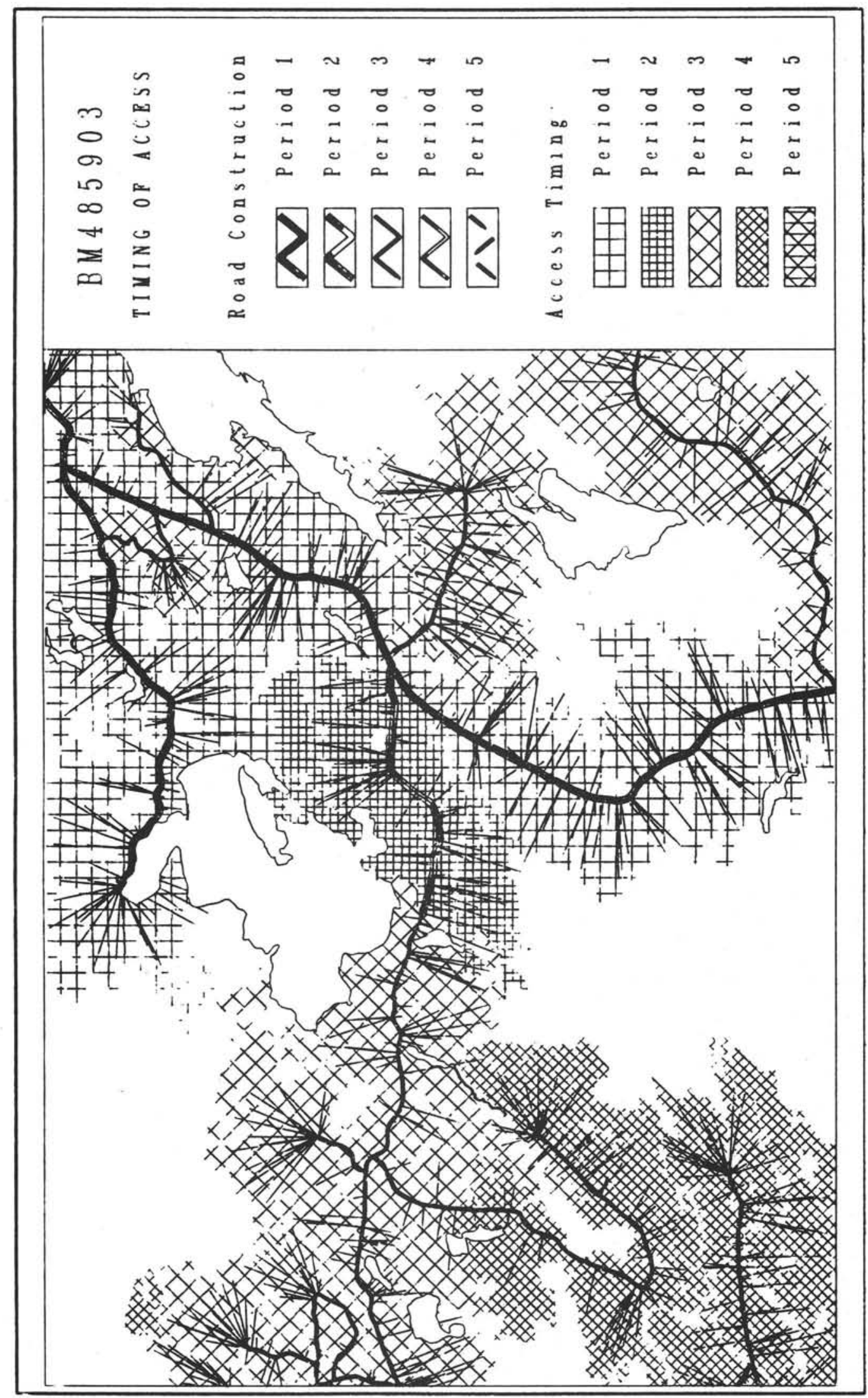

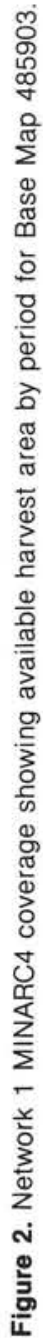




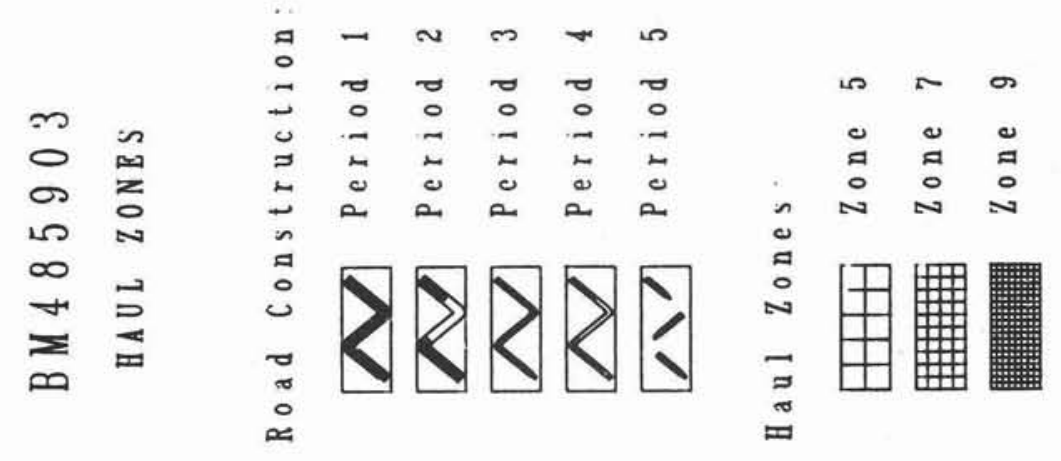

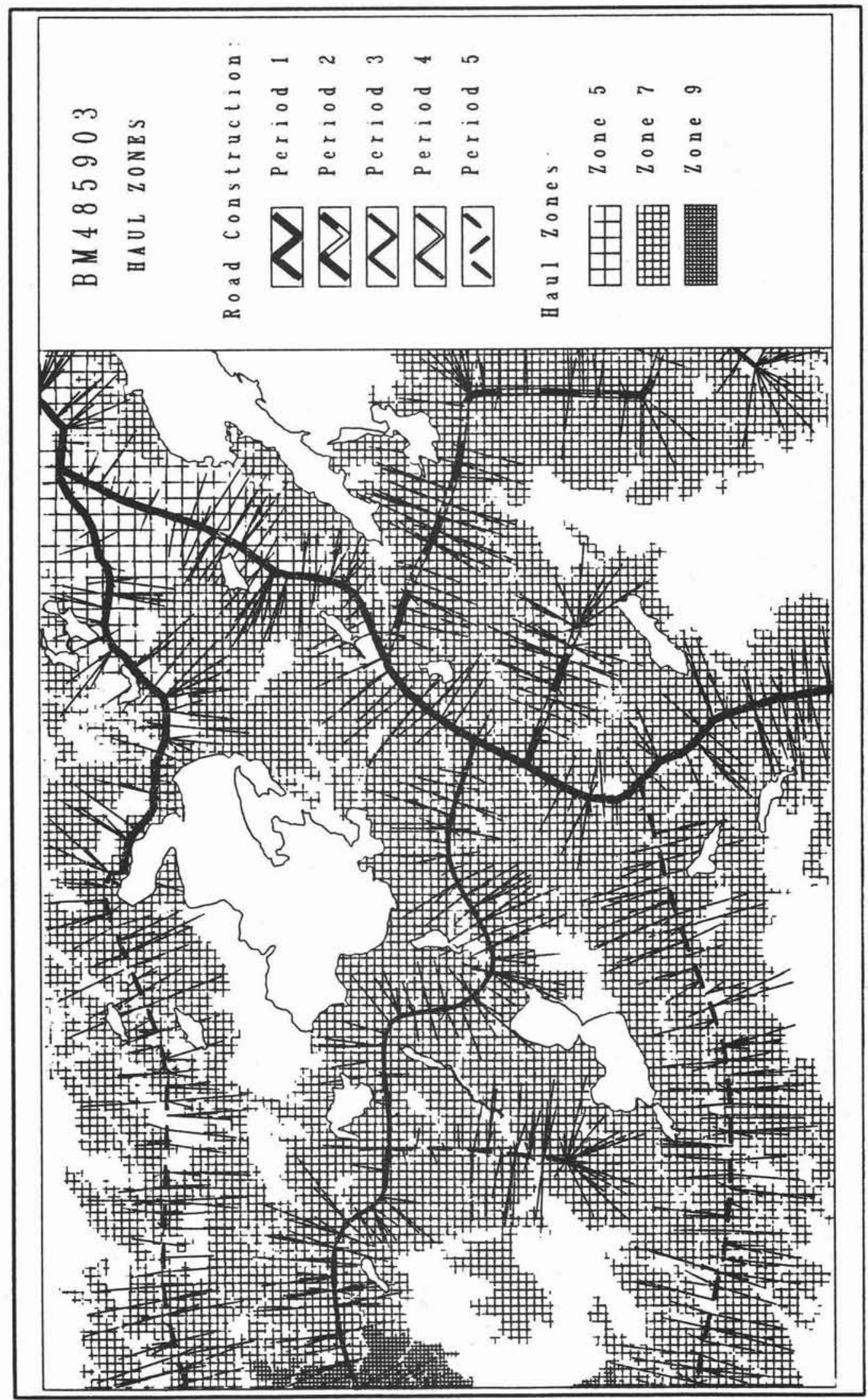

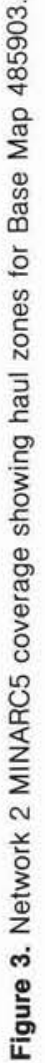




\begin{tabular}{|c|c|c|c|c|}
\hline Alternative & $\begin{array}{l}\text { Forest Base } \\
\text { (road Network) }\end{array}$ & $\begin{array}{c}\text { Access } \\
\text { Constraints }^{1}\end{array}$ & $\begin{array}{c}\text { Haul } \\
\text { Costs }\end{array}$ & $\begin{array}{l}\text { Flow Constraints } \\
\text { (percent) }\end{array}$ \\
\hline CONTROL & Full & No & $\begin{array}{l}\text { Constant } \\
\left(\$ 7 / \mathrm{m}^{3}\right)\end{array}$ & $+1-5$ \\
\hline NET1a & Network 1 & Yes & Zone & $+1-5$ \\
\hline NET2 & Network 2 & Yes & Zone & $+1-5$ \\
\hline NET1b & Network 1 & No & Zone & $+1-5$ \\
\hline NET1C & Network 1 & No & $\begin{array}{c}\text { Constant } \\
\left(\$ 7 / \mathrm{m}^{3}\right)\end{array}$ & $+1-5$ \\
\hline
\end{tabular}

1- Yes - Timing of access constraints included

No - Timing of access constraints excluded

2. Constant - All areas assumed in Zone 7

Zone - Areas stratified into Zones 5, 7, and 9

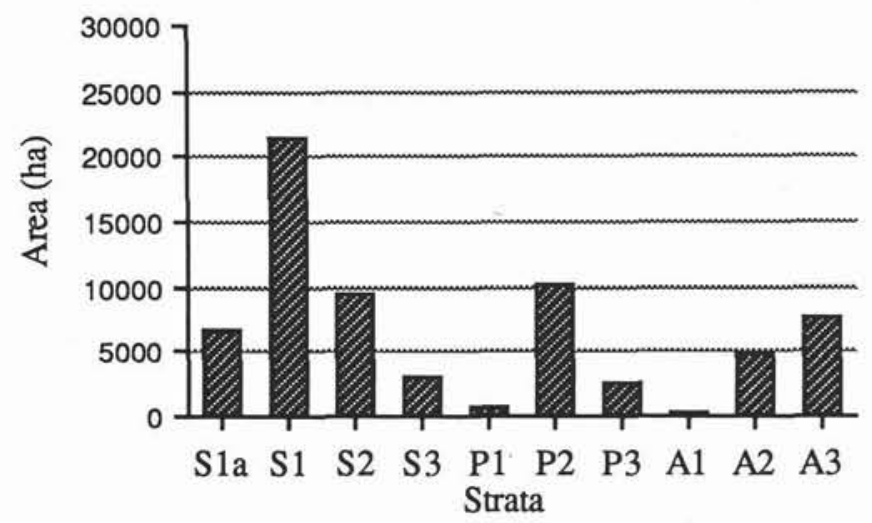

Figure 4. Forest structure of CONTROL alternative in period 5.

Area stratification for alternatives NET1a and NET1b was more complex because of the addition of haul zones and timing of access constraints. Three haul zones were defined at intervals of $\$ 2 / \mathrm{m}^{3}$. The zones were termed Zone 5, 7 and 9, corresponding to the cost per cubic metre of transportation to the mill. Each stand in the forest base was assigned to a haul zone, determined by the value of its MC (Minimum Cost) attribute. Timing-of-access constaints required five area stratifications to be performed, one for each of the first five periods. The forest base in period 1 consisted of all those stands which had the MCP (Minimum Cost Period) attribute equal to 1 . The period 1 forest base was stratified by age class within strata within haul zone. The stratification was repeated for the accumulated forest bases in each period (Figures 5 and 6). The period 5 forest base then consisted of all stands with MCP value between 1 and 5 ( 0 indicated no access, beyond search tolerance). Figures 7 and 8 depict the distribution of area among haul zones during the last period of road construction activity (final forest base) for alternatives NET1a and NET2, respectively. Both the total area by strata and the expected haul costs are affected by subjectively defined alternative road networks.

A Timber RAM datafile was created for each of the alternatives. Basic volume and economic data were the same for each alternative. Differences among alternatives resulted from the amount and timing of areas accessed, and transportation costs.

\section{Results}

Figure 9 summarizes the results of a series of simulations made with Timber RAM for the CONTROL, NET1 $a$ and NET2 alternatives. Each point represents a cost minimization objective, with a constrained harvest level over 25 years.

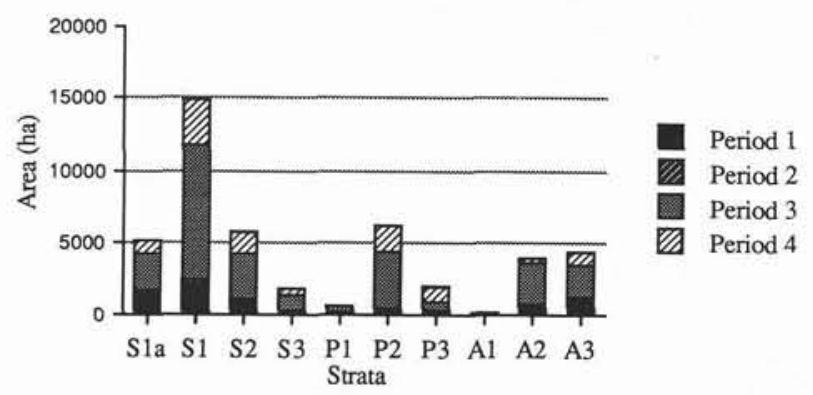

Figure 5. Forest structure of NET1a alternative by period.

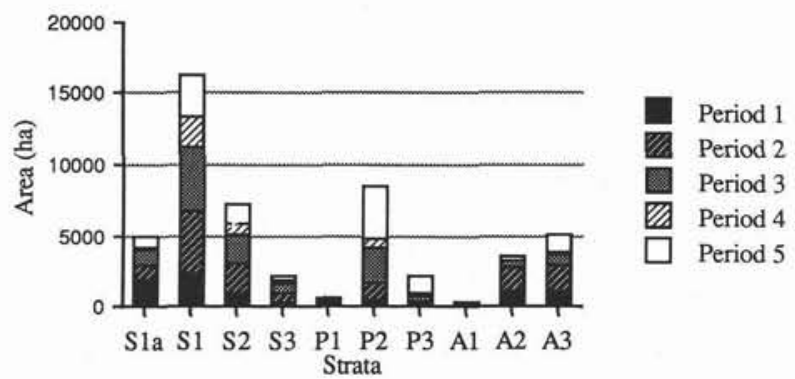

Figure 6. Forest structure of NET1b alternative by period.

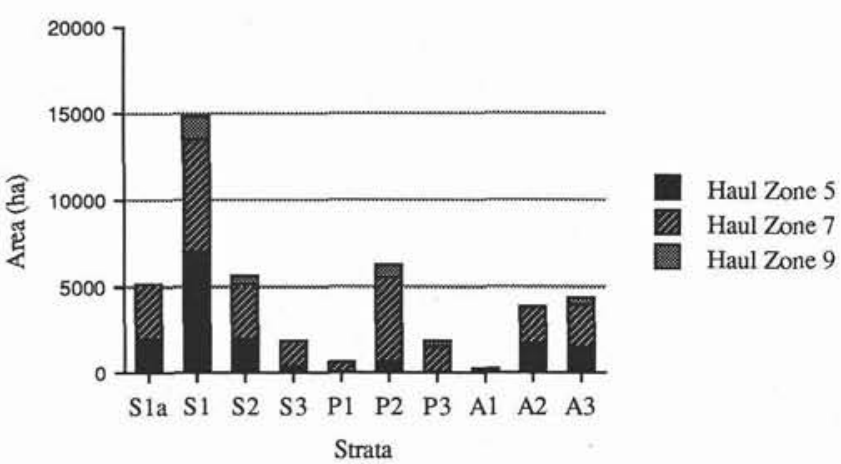

Figure 7. Forest structure of NET1a alternative in period 4 showing haul zones.

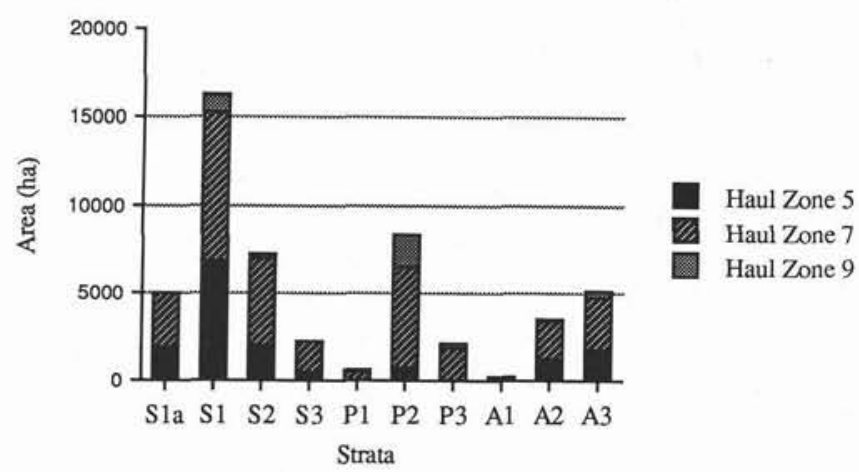

Figure 8. Forest structure of NET2 alternative in period 5 showing haul zones.

The right-most point on each curve was determined by first maximizing harvest volume, followed by minimizing costs while obtaining the maximum harvest volume.

The CONTROL mill gate costs assumed an average haul cost of $\$ 7 / \mathrm{m}^{3}$. Higher harvest levels required that increasing 


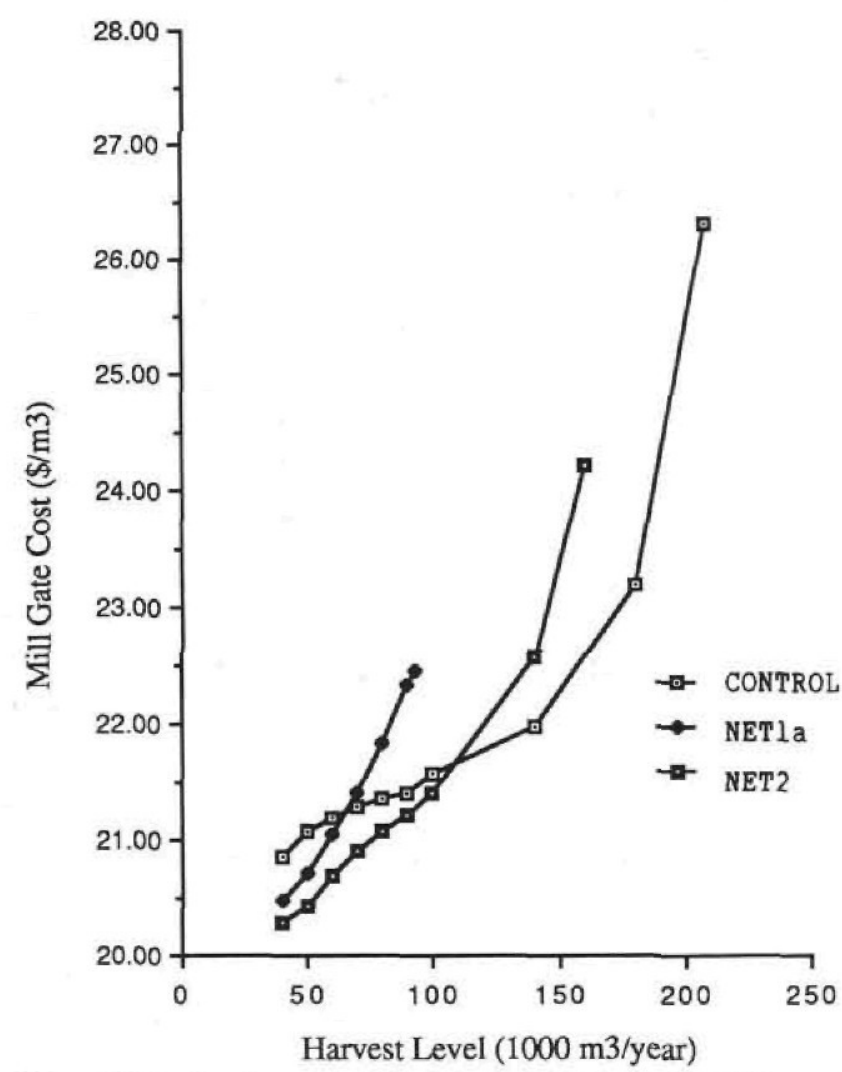

Figure 9. Production possibility curves for CONTROL, NET1a, and NET2 alternatives.

amounts of harvest area be intensively treated, at higher costs, to achieve the minimum volume constraint. At lower harvest levels, non-intensive treatment regimes were chosen, because the harvest level constraint was easily satisfied with inexpensive natural regeneration. Increasing savings would be made as volume requirements decreased.

The results of NET1a and NET2 indicate the effects of the partial forest base lowering the maximum sustainable harvest level. The total area accessed by NET2 was 50649 ha by period 5, while NET1a accessed only 44641 ha by period 5. Roading in NET2 was more intensive than NET1a, resulting in more area accessed at an earlier time. The effect on sustainable harvest is observed in Figure 9 in two ways. First, NET2 has a lower mill gate cost than NET1a throughout, caused by the larger forest base allowing more periodic harvest to be from less costly stand classes. Second, the slower rise in the slope of NET2 was the result of the larger forest base satisfying the harvest level constraint requiring less harvest area be treated intensively than NET1a at the same harvest level. Detailed harvest schedules for the various alternatives may be reviewed in Lougheed (1988).

To explore the reasons for the shape of the NET1a production possibility curve, two additional series of Timber RAM simulation runs were made. Both NET1b and NET1c omitted timing of access constraints, while only NET1b included haul costs. NET1c then was different from CONTROL only in the partial forest base. Figure 10 shows the results of these simulation runs. Removal of the timing of access constraints has the dual effect of increasing the maximum sustainable harvest level and decreasing the intensively treated area required to achieve a given harvest level, which in turn reduces the mill gate cost.

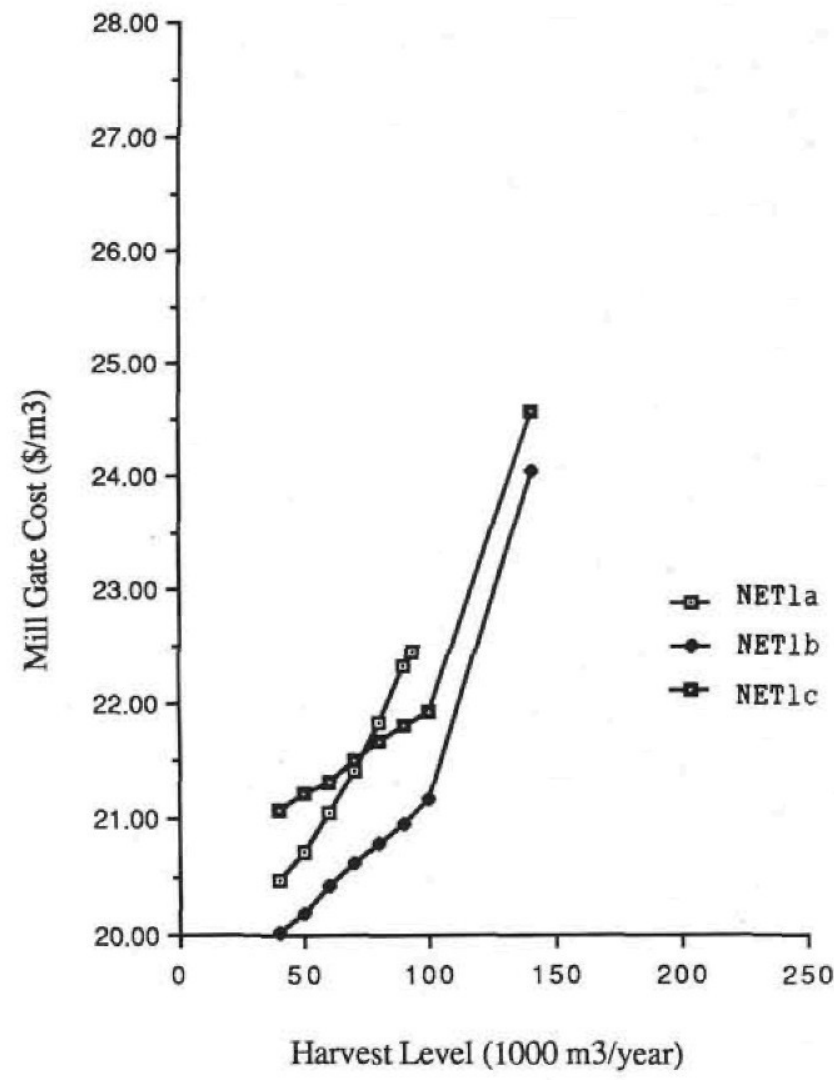

Figure 10. Production possibility curves for NET1a, NET1b, and NET1C alternatives.

\section{Discussion}

The case study showed that the planning system is capable of addressing the problem of jointly designing timber management strategies and primary road networks. For those organizations already supporting ARC/INFO and a database, the system presents an additional opportunity for exploiting GIS analytic potential. The system provides a means of determining, by period, the area available for harvest within each stand class, resulting from alternative road networks. Treatment schedules should therefore be more implementable than where timing of access is ignored, although treatments specified for each stand class in a five-year period must still be allocated by planners in terms of annual treatments to stands. This provides an opportunity for operational planning suited to the individual organization. However, usefulness of this or any planning system is still limited by the quality of the available database.

The system is not restricted to timber management planning. For example, HAULCOST could be used on a smaller time scale for operational planning. The additional attributes could also be used for producing maps of accessible areas by time period, and haul cost zones. HAULCOST can be modified to perform the analysis based on other parameters. COST.PG calculated haul costs based on travel time, but any descriptor of the arc may be used with any function to calculate impedance values to be used in the ALLOCATE procedure. Users familiar with the tool may adapt it to their particular situation.

Transferability of the system described in this paper may be difficult because of the required access to a GIS and a maintained database. Use of HAULCOST requires access to the ARCIINFO GIS. However, modifications to the various programs 
available in Lougheed (1988) and Lougheed and Walker (1988) are possible. Changes would require knowledge of Fortran programming, ARC/INFO commands and CPL programming. Modifications to the HAULCOST algorithm may require changes to only the ARC/INFO or CPL routines, a relatively simple task. Changes to the MINARC.F77 program would require knowledge of the internal ARC/INFO data structures, and would be a relatively major undertaking. Licensed software used to develop the system described in this paper includes:

- ARC/INFO Geographic Information System (ESRI 1987); - Lotus 1-2-3 spreadsheet system (Lotus Development Corporation 1985);

- WordPerfect text processing system (WordPerfect Corporation 1985):

- XMP mathematical programming system (Marsten 1986);

- F77 FORTRAN compiler (Burns 1985); and

- PRIMOS operating system (Lamb and Landy 1982).

Figure 11 shows how the various components of the planning system are linked.

Copies of Lougheed (1988) and Lougheed and Walker (1988), including the non-licensed software required to implement the system, may be obtained from:

Socio-economic Analysis and Planning Unit, Great Lakes Forestry Centre, 1219 Queen Street East, Sault Ste. Marie, Ontario P6A 5M7 CANADA

\section{Acknowledgements}

This research was funded by the Canada-Ontario Forest Resource Development Agreement, contract 31-001. Jack Smyth of the Canadian Forestry Service was Project Manager. Great Lakes Forest Products staff John Garner, Derek Dool, and Albert Sellers provided data and advice. The research was completed while both authors were affiliated with the School of Forestry at Lakehead University in Thunder Bay, Ontario. GIS and minicomputer facilities were provided by the CARIS (Centre for the Application of Resources Information Systems) facility within the School of Forestry. CARIS staff members Joe Kapron and Grant Mitchell provided programming assistance.

\section{References}

Burns, E. 1985. FORTRAN77 reference guide. Revision 19.4. Natick, MA: Prime Computer, Inc., DOC4029-4PA, var. pag

Chappelle, D.E., M. Mang and R.C. Miley. 1976. Evaluation of Timber RAM as a forest management planning tool. J. For. 74: 287-293.

Dykstra, D.P. 1984. Mathematical Programming for Natural Resource Management. Toronto: McGraw-Hill, xvi + $318 \mathrm{pp}$.

Environmental Systems Research Institute. 1987. ARC/INFO user's guide: Volume 1. Redlands, CA: Environmental Systems Research Institute, var. pages.

Great Lakes Forest Products Ltd. n.d. Logging chance maps. Thunder Bay, ON: Great Lakes Forest Products Ltd

Henco Software Inc. 1985. INFO Prime reference manual, revision 9.3, February 1985. Waltham, MA: Henco Software Inc., var. pag.

Iverson, D.C. and R.M. Alston. 1986. The genesis of FORPLAN: A historical and analytical review of Forest Service planning models. USDA For. Serv. Intermountain Res. Stn., Gen Tech. Rept. INT-214, $31 \mathrm{pp}$.

Johnson, K.N. and D.B. Jones. 1980. MUSYC: Timber harvest scheduling model user's guide and operations manual. Fort Collins, CO.: WO Timber Mgmt. Unit, var. pages.

Johnson, K.N., T.W. Stuart and S.A. Crim. 1986. FORPLAN Version 2: An overview. Fort Collins, CO.: Land Mgmt. Planning Syst. Sect., var. pages.

Jones, J.G., J.F.C. Hyde III and M.L. Meacham. 1986. Four analyt ical approaches for integrating land management and transportation planning on forest lands. USDA For. Serv., Intermountain Research Stn., Res. Pap. INT-361, 33 pp.

Kirby, M.W., W.A. Hager and P. Wong. 1986. Simultaneous planning of wildland management and transportation alternatives. Pp. 371-387 In Kallio, M., A.E. Anderson, R. Seppala and A. Morgan (eds.) 1986. Systems Analysis in Forestry and Forest

PR1ME Minicomputer

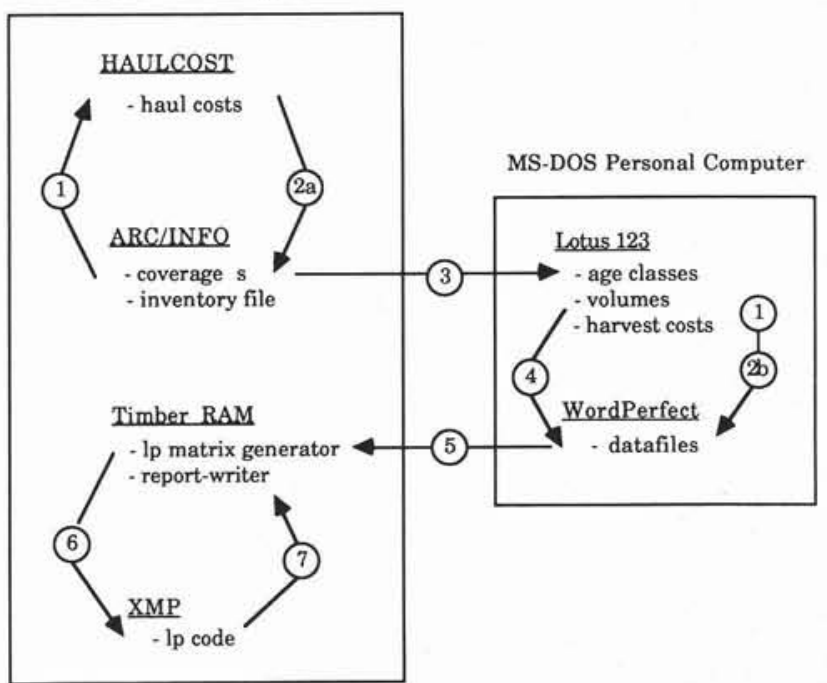
1) Acquire data
volumes and harvest costs (PC)
coverages and inventory files (Prime)

2) Derive data

2a) - spatial (haul costs and

timing of access by stand)

(2) - non-spatial (volume and economic classes)

(3) Transfer data (Kermit)

- Prime to PC

Figure 11. Linkages among system components.

Industries, TIMS studies in the management sciences, Volume 21. New York: Elsevier Science Publishers, $487 \mathrm{pp}$.

Lamb, S. and A. Landy. 1982. PRIMOS commands reference guide. Revision 19.0. Natick, MA: Prime Computer, Inc. FDR3108-190P, var. pag

Landy, A. 1986. CPL User's Guide, DOC4502-190, Revision 19. Framingham, MA: Prime Computer Inc., var. pages.

Lotus Development Corporation. 1985. Lotus 1-2-3 reference manual. Cambridge, MA: Lotus Development Corporation, vii + $350 \mathrm{pp}$.

Lougheed, W.H. 1988. Spatial analysis in timber management planning. Unpub. M.Sc.F. thesis, Lakehead Univ., viii + $150 \mathrm{pp}$.

Lougheed, W.H. and H.D. Walker. 1988. Haulcost users' guide. Thunder Bay, ON: School For., Lakehead Univ, iv + 31 pp.

Marsten, R.E. 1986. The ZOOM/XMP mixed integer programming system. Tucson, AR: var. pag.

Navon, D.I. 1971. Timber RAM ... a long-range planning method for commercial timber lands under multiple-use management. USDA For. Serv., Pacific Southwest For, and Range Exp. Stn., Res. Pap. PSW-70, 22 pp.

Ontario Ministry of Natural Resources. 1985. Forest management agreement between the Minister of Natural Resources and Great Lakes Forest Products Ltd. Toronto: Ont. Min. Nat. Resour., 24 pp. + schedules.

Plonski, W.L. 1981. Normal yield tables (metric) for major forest species of Ontario. Toronto: Ont. Min. Nat. Resour., For. Resour. Group, $40 \mathrm{pp}$

Weintraub, A. and D. Navon. 1976. A forest management planning model integrating silvicultural and transportation activities. Mgmt. Sci. 22: 1299-1309.

WordPerfect Corporation. 1986. WordPerfect word processing software reference manual, version 4.1. Orem, UT: Wordperfect Corporation, var, pag. 